\title{
Malocclusion Impact Scale for Early Childhood (MIS-EC): development and validation
}

\author{
Márcio Alexandre HOMEM(a) \\ Maria Letícia RAMOS-JORGE ${ }^{(b)}$ i \\ Isabella MOTA-VELOSO(a) (ID) \\ Tulio Silva PEREIRA ${ }^{(b)}$ iD \\ Paulo Antônio MARTINS-JÚNIOR ${ }^{(a)}$ \\ David NORMANDO(c) \\ Saul Martins PAIVA(a) \\ Isabela Almeida PORDEUS(a) \\ Carlos FLORES-MIR(d) \\ Leandro Silva MARQUES(b)
}

(a) Universidade Federal de Minas Gerais UFMG, School of Dentistry, Department of Paediatric Dentistry, Belo Horizonte, MG, Brazil.

(b) Universidade Federal dos Vales do Jequitinhonha e Mucuri - UFVJM, School of Dentistry, Department of Paediatric Dentistry, Diamantina, MG, Brazil.

(c) Universidade Federal do Pará - UFPA, Department of Orthodontics, Belém, PA, Brazil.

(d) University of Alberta, Faculty of Medicine and Dentistry, School of Dentistry,

Edmonton, Canada.

Declaration of Interests: The authors certify that they have no commercial or associative interest that represents a conflict of interest in connection with the manuscript.

\section{Corresponding Author:}

Leandro Silva Marques

E-mail: Ismarques.prof@gmail.com

https://doi.org/10.1590/1807-3107bor-2021.vol35.0068

Submitted: January 20,2019

Accepted for publication: January 21, 2020

Last revision: February 11, 2021
Abstract: This study aimed to develop and validate the Malocclusion Impact Scale for Early Childhood (MIS-EC), a malocclusion-specific measure of oral health-related quality of life (OHRQoL) of children aged 3-5 years and their parents/caregivers. A pool of items was analysed to identify those relevant to the assessment of the impact of malocclusion on OHRQoL. Dental professionals and mothers of children with and without malocclusion rated the importance of these items. The final version of the MIS-EC was evaluated in a cross-sectional study comprising 381 parents of children aged 3-5 years to assess construct validity, internal consistency and test-retest reliability. Twenty-two items were identified from item pooling. After item reduction, eight items were chosen to constitute the MIS-EC, in addition to two general questions. The MIS-EC demonstrated good internal consistency (Cronbach's alpha $=0.79$ for the Child Impact section and 0.53 for the Family Impact section), and excellent test-retest reliability (ICC $=0.94$ ), floor effect was $55.7 \%$ and ceiling effect $0 \%$. MIS-EC scores indicating worse OHRQoL were significantly associated with the presence of malocclusion ( $p<0.05)$. The MIS-EC is reliable and valid for assessing the impact of malocclusion on the OHRQoL of preschool children and their parents/caregivers.

Keywords: Malocclusion; Quality of Life; Child, Preschool; Tooth, Deciduous.

\section{Introduction}

During the last decades, various assessment tools have been developed to measure the impact of oral problems on the oral health-related quality of life (OHRQoL) of individuals, three of which have been focused on preschool children. ${ }^{1,2,3,4,5,6,7}$ In general, these studies agreed that these generic instruments can evaluate the impact of dental caries and traumatic dental injuries (TDI) well on the OHRQoL of preschool children and their parents, but divergent results were identified in relation to the impact of malocclusion. ${ }^{7,8,9,10,11}$

It has been recognized that generic measures are more useful to compare populations and can be used to compare groups with different health conditions. On the other hand, condition-specific measures are more sensitive and responsive at measuring changes in individuals with a 
specific disease. ${ }^{12,13}$ Thus, the absence of solid evidence about the impact of malocclusion on the OHRQoL of preschool children and their parents/caregivers can be due the fact that all studies that tried to establish associations between malocclusion and OHRQoL used generic instruments instead of condition-specific one. Thus, this lack of reliable evidence may be associated with the need for development of a sensitive assessment tool specific to this purpose. Indeed, a specific tool to identify the impact of malocclusion on the primary dentition may favour the development of strategies to prevent problems related to psychological issues as well as prevention and treatment of already established disorders that may interfere with the normal development of dental arches.

Therefore, the aim of the present study was to develop and validate the Malocclusion Impact Scale for Early Childhood (MIS-EC), which is a specific assessment tool designed to measure the impact of malocclusion on the OHRQoL of children aged three to five years and their parents/caregivers using parental reports.

\section{Methodology}

\section{Ethical approval}

This study received approval from the Human Research Ethics Committee of the Federal University of Vales do Jequitinhonha and Mucuri (UFVJM), protocol 181/10.

\section{Item generation}

This initial phase aimed to generate potential items that will constitute the new assessment tool. Thus, thirty-six previously used items were analysed and modified by a team of four researchers with experience in paediatric dentistry and orthodontics. The selected items were identified from OHRQoL assessment tools that had been already adapted and validated for use on Brazilian children. 1,2,4,5,6,7,14,15,16,17,18,19,20 The team of researchers identified 22 items to be further analyzed in the item reduction phase. As many of the items on the questionnaire addressed the same issues, some of the items identified as relevant during the analysis either coincided or were very similar to each other. The researchers determined by consensus whether to maintain or remove items. In some cases, the items were rewritten. The items addressed the entire life of the child rather than limiting the scope to the previous three months. This was done due to the age of the target population (three to five years) and difficulties on the part of caregivers about the certification of precisely when a child experienced a problem, as demonstrated in a previous study.

\section{Item reduction}

Fifteen oral healthcare professionals with experience in clinical-epidemiological studies in the fields of paediatric dentistry and orthodontics, mothers of children aged 3-5 years that had malocclusion $(n=15)$ and mothers of children that had no malocclusion $(n=15)$ participated in the item reduction phase. None of the children included in this stage of the study had experienced toothache due to dental caries or had suffered a TDI. Although larger samples have been used in previous studies, ${ }^{18}$ the smaller number of participants used herein allowed an in-depth discussion of the items with the participants. ${ }^{13}$ The set of 22 items was presented to the group of dental professionals and mothers, who indicated their opinions about the relevance of each item using a visual analogue scale (VAS) ranging from zero (no relevance) to 10 (highly relevant) points. At the end of this process, a trained researcher asked each participant about difficulties in understanding the questions. Using the domains identified in previous studies ${ }^{1,19}$ as a guide, the 22 items included two general questions as well as 20 questions distributed among six domains and divided into two sections. The Child Impact section comprised four domains: oral symptoms (3 items), functional limitations (6 items), psychological impact (3 items) and social interaction/self-image (4 items). The Family Impact section comprised two domains: parental distress (2 items) and family function (2 items).

The total VAS score (0 to 10$)$, mean score and standard deviation were calculated for each of the 22 items. For standardization purposes, the total score of each item was subtracted from the corresponding mean score and divided by its standard deviation. Each item was then classified in decreasing order 
of importance based on the standardized scores. Items with a low standardized score $(<2$ points) were not considered relevant to the evaluation of the impact of malocclusion on the OHRQoL of preschool children and were therefore excluded (12 items). Based on this decision, in the Child Impact section items related to pain, gingival bleeding and mouth sores (oral symptoms), those related to difficulty drinking with a straw, sleeping, oral hygiene and mouth breathing (functional limitations), those related to being concerned that one's physical appearance was not as good as that of others (psychological impact) and those related to avoiding activities, such as playing and going to preschool/day care (social interaction/self-image), were excluded.

Some items were ranked differently between the groups of dental professionals and mothers. Such items on the Child Impact section were related to mouth breathing and gingival bleeding, which were not considered relevant to the evaluation of the impact of malocclusion on OHRQoL by consensus of the researchers. On the Family Impact section, items related to feelings of parental guilt and the need to miss work also had the same discrepancy in the ranking. Thus, the consensus of the researchers was to unite the two items addressing parental distress, with the following question remaining in the final version: "Have you or another member of your family ever felt upset or guilty due to bite problems or the positioning of the teeth of your child?" As no statistically significant difference were found between the groups about the other three items (mouth breathing, gingival bleeding or missing work) (Mann-Whitney $U$-test, $\mathrm{p}>0.05$ ), the researchers decided to exclude these items.

\section{Pre-test}

The final version of the MIS-EC was self-administrated to 40 mothers of preschool children randomly selected at a day care centre to evaluate the ease of interpretation, problems related to the comprehension of the items and the efficacy of the self-administration of the questionnaire. As mothers reported no difficulties in interpreting or understanding the scale, no further changes were deemed necessary.

\section{Scores and analysis of MIS-EC for evaluation of validity and reliability}

The final version of the MIS-EC comprised 8 items: six questions on the Child Impact section and two on the Family Impact section (Figure 1). Besides that, two general questions were constructed, however, these questions are not part of the MIS-EC. The Child Impact section was divided into three domains (functional limitations, psychological impact and social interaction/self-image) and the Family Impact section was divided into two domains (parental distress and financial impact). The following were the general questions:

a. How would you evaluate the health of your child's teeth, mouth, lips and jaws (bones of the oral cavity)? (very good $=0$, good $=1$, fair $=2$, poor $=3$, very poor $=4$ and I don't know $=$ score not attributed);

b. Does the condition of your child's teeth, mouth, lips and jaws compromise his/her general wellbeing? (never $=0$, hardly ever $=1$, sometimes $=2$, often $=3$, very often $=4$ and $\mathrm{I}$ don't know $=$ score not attributed).

For the eight questions, the response options were never $=0$, hardly ever $=1$, sometimes $=2$, often $=3$, very often $=4$ and I don't know $=$ score not attributed. The total score of these eight questions was determined by the sum of the item scores (range: 0 to 32), with the "I don't know" responses considered missing data. Questionnaires with two or more missing or "I don't know" responses were excluded from the analysis. The score on the Child Impact and Family Impact section therefore ranged from 0 to 24 points and 0 to 8 points, respectively. The MIS-EC was developed in Brazilian Portuguese language.

\section{Validity and reliability}

\section{Subjects and study design}

The validation of the MIS-EC was conducted with a sample composed of preschool children aged 3-5 years and their parents/caregivers selected from public day care centres in the city of Diamantina, Brazil. The sample size was estimated based on the data from a pilot study. The parameters used 


\section{MALOCCLUSION IMPACT SCALE FOR EARLY CHILDHOOD (MIS-EC)}

Este questionário pergunta sobre problemas relacionados aos dentes ou a boca da sua criança que podem afetar a qualidade de vida dela e de sua família. Por favor, marque a melhor resposta para cada pergunta. Considere toda a vida da sua criança, desde o nascimento até agora, quando responder a cada pergunta.

\section{Impacto da Criança}

1. Sua criança já teve dificuldade para comer ou morder certos alimentos (por exemplo: maça, pão, espiga de milho ou carne) devido a problemas de mordida ou posicionamento dos dentes?

( ) Nunca ( ) Quase nunca ( ) Às vezes ( ) Com frequência ( ) Com muita frequência ( ) Não sei

2. Sua criança já evitou falar ou teve dificuldade de pronunciar alguma palavra devido a problemas de mordida, posicionamento dos dentes ou uso de aparelho ortodôntico?

( ) Nunca ( ) Quase nunca ( ) Às vezes ( ) Com frequência ( ) Com muita frequência ( ) Não sei

3. Sua criança já ficou irritada ou frustrada devido a problemas de mordida, posicionamento dos dentes ou por uso de aparelho ortodôntico?

( ) Nunca ( ) Quase nunca ( ) Às vezes ( ) Com frequência ( ) Com muita frequência ( ) Não sei

4. Sua criança já agiu de modo tímido, constrangido, com vergonha ou já ficou preocupada por achar que sua aparência não é tão boa como a das outras pessoas (por causa dos problemas de mordida ou posicionamento dos dentes)?

( ) Nunca ( ) Quase nunca ( ) Às vezes ( ) Com frequência ( ) Com muita frequência ( ) Não sei

5. Sua criança já evitou sorrir ou rir devido a problemas de mordida ou posicionamento dos dentes?

( ) Nunca ( ) Quase nunca ( ) Às vezes ( ) Com frequência ( ) Com muita frequência ( ) Não sei

6. Sua criança já foi alvo de brincadeiras ou apelidos por parte de outras crianças (por causa de problemas de mordida ou posicionamento dos dentes)?

( ) Nunca ( ) Quase nunca ( ) Às vezes ( ) Com frequência ( ) Com muita frequência ( ) Não sei

\section{Impacto da Família}

7. Você ou outra pessoa da família já se sentiu aborrecida ou culpada devido a problemas de mordida ou posicionamento dos dentes?

( ) Nunca ( ) Quase nunca ( ) Às vezes ( ) Com frequência ( ) Com muita frequência ( ) Não sei

8. Sua criança já teve problemas de mordida ou posicionamento dos dentes ou fez tratamentos ortodônticos que causou custo financeiro para sua família?

( ) Nunca ( ) Quase nunca ( ) Às vezes ( ) Com frequência ( ) Com muita frequência ( ) Não sei

\section{Limitações funcionais}

Impacto psicológico

Autoestima/Interação social

Sofrimento dos pais

Função da família

Figure 1. The Malocclusion Impact Scale for Early Childhood (MIS-EC) in Brazilian Portuguese language.

for the calculation were a $95 \%$ confidence interval (CI), $80 \%$ statistical power, a standard deviation of 3.2 and minimum difference of 1 point in the MIS-EC score detected between groups with and without malocclusion for a two-tailed hypothesis. Thus, a minimum of 161 participants was needed for each group, to which 60 children per group were added to compensate for possible dropouts (total sample: 442 children).

To participate in the study, parents/caregivers needed to be fluent in Brazilian Portuguese. The exclusion criteria were the presence of erupted permanent teeth, toothache due to dental caries or TDI in the month prior to the clinical examination and a past history of orthodontic appliance use or orthodontic treatment during the data collection period.

From the initial 442 participants, twenty children were excluded for having a permanent first molar,
18 were excluded due to toothache in the previous month and eight were excluded due to having experienced TDI in the previous month. Moreover, 15 children were excluded at the end of the analysis due to incomplete information on the questionnaire ( $n=11$ ) or questionnaires with two or more "I don't know" responses $(\mathrm{n}=4)$.

\section{Data collection}

The data were determined through a clinical oral examination of the children and questionnaires filled out by the parents/caregivers. Besides the MIS-EC, parents/caregivers answered a questionnaire addressing socio-demographic information. In family structure, nuclear family was constituted by father, mother and child/children living together and non-nuclear when they were not living in the same house. 
The field team consisted of two paediatric dentists and two annotators. One examiner was in charge of examining for dental caries and TDI and the other was in charge of determining the occurrence of malocclusion. The examiners had undergone both theoretical and practical exercises for the diagnosis of these oral conditions. Weighted (dental caries) and simple (malocclusion and TDI) Kappa coefficients were calculated for the determination of inter-examiner and intra-examiner agreement. Kappa values were higher than 0.8 for all oral conditions evaluated.

Dental caries and TDI were evaluated as possible confounding variables. The criteria of the World Health Organization $(\mathrm{WHO})^{21}$ were used for the evaluation of decayed, missing and filled teeth ( $\mathrm{dmft}$ index). The $\mathrm{dmft}$ was dichotomised as caries free $(\mathrm{dmft}=0)$ and with caries $(\mathrm{dmft} \geq 1)$. TDI was determined using the criteria established by Andreasen and Lovschall ${ }^{22}$ and dichotomized as the absence or presence of at least one type of trauma.

Malocclusion was classified based on standardized previously published criteria ${ }^{23}$ for anterior open bite, defined as the absence of vertical overlap of the mandibular incisors, incisor overjet, measured as the distance between the palatal surfaces of the most projected maxillary incisor and corresponding mandibular incisor and subsequently classified as normal $(\leq 3 \mathrm{~mm})$ or increased $(>3 \mathrm{~mm})$, anterior crossbite, maxillary anterior teeth occluding lingually to mandibular anterior teeth and posterior crossbite, maxillary molars occluding lingually to mandibular molars. The measurement was performed with the teeth in centric occlusion and the periodontal probe positioned parallel to occlusal plane. The children were categorized as having a malocclusion or not based on the presence of at least one of these conditions.

\section{Data analysis}

Data analysis was performed using the Statistical Package for Social Sciences (SPSS for Windows, version 20.0, SPSS Inc. Chicago, IL, USA). Descriptive analysis (Mean, standard deviations, score range, and percentage of patients with the lowest (floor effect) and highest theoretical scores (ceiling effect) were calculated in order to examine the scores' distribution of the MIS-EC) was performed for the independent variables as well as the mean total MIS-EC and subscale scores. The Kolmogorov-Smirnov test was used to evaluate the normality of the distribution of the quantitative variables.

Convergent validity was evaluated through the calculation of Spearman's correlation coefficients: a) among the scores of the Child Impact section, Family Impact section and two general questions of the scale; b) among the scores of the Child Impact section, Family Impact section and total MIS-EC score. Values of 0.00 to 0.20 would indicate poor correlation; values from 0.21 to 0.40 would indicate fair correlation; values from 0.41 to 0.60 would indicate moderate correlation; values from 0.61 to 0.80 would indicate good correlation and values from 0.81 to 1.00 , would indicate excellent correlation. ${ }^{24}$

Internal consistency was evaluated for the overall sample $(n=381)$. Values of Cronbach's alpha 0.70 or higher would be acceptable. ${ }^{25}$ Test-retest reliability was evaluated using the intraclass correlation coefficient (ICC) through the administration of the MIS-EC on two separate occasions with a two-week interval between administrations to a convenience sample of mothers of preschool children recruited at the same day care centres $(n=40)$. ICC values lower than 0.40 would indicate inferior; 0.41 to 0.60 would indicate moderate, values of 0.61 to 0.80 would indicate good and higher than 0.80 excellent repeatability. ${ }^{26,27}$

To evaluate discriminant validity, differences in the mean scores of the total MIS-EC and sections (Child and Family) between children with malocclusion and those without malocclusion were determined using the Mann-Whitney $U$-test.

The flow chart summarizes the process of development and validation of the MIS-EC (Figure 2).

\section{Results}

\section{Overview of MIS-EC}

The validity and reliability of the MIS-EC were evaluated using a sample of 381 children and their parents/caregivers, giving a response rate of $86.2 \%$ from the original approached sample. Mothers accounted for $87.0 \%$ of the caregivers who answered the questionnaires. Table 1 displays the absolute and relative values for the socio-demographic and 


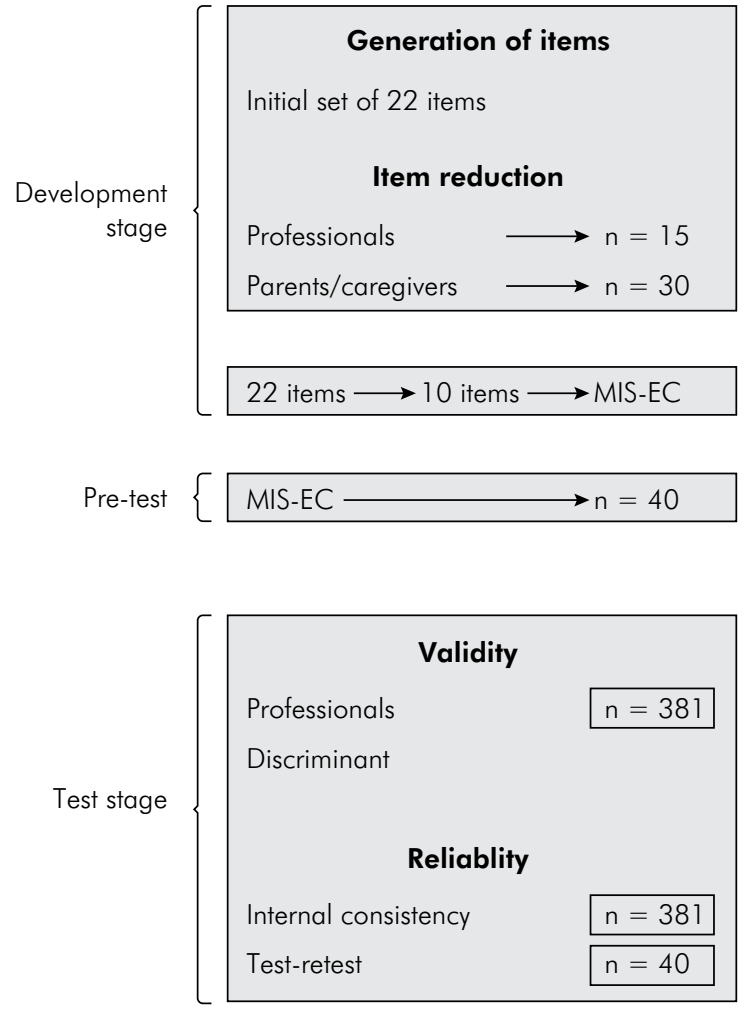

Figure 2. Flow chart describing the process of development and validation of the Malocclusion Impact Scale for Early Childhood (MIS-EC).

clinical oral variables. Mean age of the children was 4.34 years $(\mathrm{SD}=0.76)$. Thirty-six children exhibited more than one type of malocclusion. Dental caries and dental trauma were present in $47.0 \%$ and $23.4 \%$ of the children, respectively.

Table 2 displays the mean, central tendency and variability measures for the overall MIS-EC as well as the different sections and domains. The majority of caregivers (59.2\%) rated their child's oral health as good or very good and $62.9 \%$ reported that their child's oral health never exerted a negative impact on his/her overall wellbeing [floor effect (lowest possible score of 0 )]. In relation to the total MIS-EC score, $42.0 \%$ of the parents/caregivers reported some impact on the OHRQoL (MIS-EC $\geq 1$ ), with a greater frequency of impact on the Child Impact section $(38.1 \%)$ than on the Family Impact section (31.0\%). The ceiling effect was observed for the Family Impact section (score of 8), but not for the Child Impact section (i.e., score of 24). The floor
Table 1. Descriptive analysis of socio-demographic and clinical oral variables of preschool children $(n=381)$.

\begin{tabular}{|c|c|}
\hline Variables & $n(\%)$ \\
\hline \multicolumn{2}{|l|}{ Socio-demographic variables } \\
\hline \multicolumn{2}{|l|}{ Sex } \\
\hline Male & 189 (49.6) \\
\hline Female & $192(50.4)$ \\
\hline \multicolumn{2}{|l|}{ Age (years) } \\
\hline 3 & $67(17.6)$ \\
\hline 4 & $116(30.4)$ \\
\hline 5 & $198(52.0)$ \\
\hline \multicolumn{2}{|l|}{ Mother's schooling (years) } \\
\hline$<5$ years & $52(13.6)$ \\
\hline $5-8$ & $89(23.4)$ \\
\hline $9-11$ & $177(46.5)$ \\
\hline$>11$ & $63(16.5)$ \\
\hline \multicolumn{2}{|l|}{ Family structure } \\
\hline Nuclear & $247(64.8)$ \\
\hline Non-nuclear & $134(35.2)$ \\
\hline \multicolumn{2}{|l|}{ Monthly household income } \\
\hline$<1$ minimum salary & $96(25.2)$ \\
\hline 1-2 times minimum salary & $185(48.6)$ \\
\hline$>2$ times minimum salary & $100(26.2)$ \\
\hline \multicolumn{2}{|l|}{ Clinical oral conditions } \\
\hline \multicolumn{2}{|l|}{ Malocclusion } \\
\hline Absent & $217(57.0)$ \\
\hline Present & $164(43.0)$ \\
\hline \multicolumn{2}{|l|}{ Anterior open bite } \\
\hline Absent & $341(89.5)$ \\
\hline Present & $40(10.5)$ \\
\hline \multicolumn{2}{|l|}{ Incisor overjet $>3 \mathrm{~mm}$} \\
\hline Absent & $321(84.3)$ \\
\hline Present & $60(15.7)$ \\
\hline \multicolumn{2}{|l|}{ Anterior crossbite } \\
\hline Absent & $315(82.7)$ \\
\hline Present & $66(17.3)$ \\
\hline \multicolumn{2}{|l|}{ Posterior crossbite } \\
\hline Absent & $347(91.1)$ \\
\hline Present & $34(8.9)$ \\
\hline \multicolumn{2}{|l|}{ Dental caries } \\
\hline Absent & $202(53.0)$ \\
\hline Present & $179(47.0)$ \\
\hline \multicolumn{2}{|l|}{ Dental trauma } \\
\hline Absent & $292(76.6)$ \\
\hline Present & 89 (23.4) \\
\hline
\end{tabular}

effect was $55.7 \%$ and ceiling effect was $0 \%$ for the total score. The items with the greatest frequency 
Table 2. Mean, standard deviation (SD), median and range of MIS-EC scores $(n=381)$.

\begin{tabular}{llcc}
\hline MIS-EC & Mean (SD) & Median & Range \\
\hline Total MIS-EC score (0-32) & $2.72(4.51)$ & 0.00 & $0-28$ \\
Child Impact section (0-24) & $2.20(3.67)$ & 0.00 & $0-20$ \\
$\quad$ Function (0-08) & $1.20(1.90)$ & 0.00 & $0-08$ \\
Psychological (0-04) & $0.27(0.81)$ & 0.00 & $0-04$ \\
$\quad$ Social interaction/Self-image (0-12) & $0.72(1.71)$ & 0.00 & $0-10$ \\
Family Impact section (0-08) & $0.84(1.45)$ & 0.00 & $0-08$ \\
$\quad$ Parental distress (0-04) & $0.67(1.16)$ & 0.00 & $0-04$ \\
$\quad$ Family function (0-04) & $0.16(0.54)$ & 0.00 & $0-04$ \\
\hline
\end{tabular}

of impact were "eating or biting certain foods" (32.7\%), "been upset or felt guilty" (30.0\%) and "avoided speaking or "had difficulty pronouncing words" (25.2\%). The following items received the most "I don't know" responses: "Does the condition of your child's teeth or mouth compromise his/her general wellbeing?" and "Has your child even been teased or called names by other children because of bite problems or the positioning of his/her teeth?", for which the response rate was $3.8 \%$ and $3.4 \%$, respectively.

\section{Validity and reliability}

Convergent validity was confirmed. The MIS-EC scores were significantly correlated $(p<0.001)$ with the overall oral health and general wellbeing measures. Cronbach's alpha coefficients were determined for the evaluation of the internal consistency of the MIS-EC items and sections and ICCs were calculated for test-test reliability (Table 3). The evaluation of discriminant validity demonstrated that children with malocclusion had higher total MIS-EC scores (Table 4), indicating a greater negative impact on the OHRQoL in comparison to children without malocclusion.

\section{Discussion}

The present study described the development and validation process of the MIS-EC for the evaluation of the impact of malocclusion on the OHRQoL of preschool children and their parents/caregivers. The MIS-EC is an eight-item

Table 3. Internal consistency and convergent validity of MIS-EC.

\begin{tabular}{lccc}
\hline Variables & Total MIS-EC score & Child impact section & Family impact section \\
\hline Number of items & 8 & 6 & 2 \\
Cronbach's alpha & 0.87 & 0.79 & 0.53 \\
ICC & 0.94 & 0.69 & 0.97 \\
Spearman's r & & & $0.30^{*}$ \\
$\quad$ Overall oral health & $0.33^{*}$ & $0.39^{*}$ & $0.41^{*}$ \\
$\quad$ General wellbeing & $0.59^{*}$ & $0.64^{*}$ & \\
\hline
\end{tabular}

*Statistical significance ( $<0.001$ ); ICC: Intraclass correlation coefficient

Table 4. Discriminant validity of MIS-EC.

\begin{tabular}{|c|c|c|c|c|c|c|}
\hline \multirow{2}{*}{ Variables } & \multicolumn{2}{|c|}{ Total MIS-EC } & \multicolumn{2}{|c|}{ Child impact section } & \multicolumn{2}{|c|}{ Family impact section } \\
\hline & Mean (SD) & Median $\left(25^{\text {th }}-75^{\text {th }}\right)$ & Mean (SD) & Median (25th-75th) & Mean (SD) & Median (25th-75th) \\
\hline \multicolumn{7}{|c|}{ Malocclusion } \\
\hline Absent & $1.72(4.01)$ & $0.00(0.00-2.00)$ & $1.65(3.37)$ & $0.00(0.00-2.00)$ & $0.52(1.15)$ & $0.00(0.00-0.00)$ \\
\hline Present & $4.02(4.81)$ & $2.00^{* a}(0.00-4.00)$ & 2.59 (3.88) & $1.00 *^{* a}(0.00-2.00)$ & $1.06(1.62)$ & $0.00 *^{* a}(0.0 .00-2.00)$ \\
\hline
\end{tabular}

Mann-Whitney U-test; ${ }^{a} p<0.001$ 
scale divided between the Child (six items) and Family (two items) Impact sections, in addition to two general questions. To the best of our knowledge, this is the first study to develop a measure for the specific assessment of the impact of malocclusion on OHRQoL among preschool children and their parents/caregivers.

In this context, previous studies offer divergent findings about the impact of malocclusion on the OHRQoL of preschool children and suggest that no existing assessment tools are sensitive enough to detect such impact. ${ }^{5,28,29,30}$ Some studies have associated the specificity of an assessment tool with its sensitivity to detect of the impact of specific clinical conditions, whereas generic assessment tools tend to not exhibit a significant association between these aspects. ${ }^{31}$ This underscores the importance of designing a specific assessment tool that evaluates the impact of malocclusion on the OHRQoL of preschool children, such as the MIS-EC, which proved to be sensitive in this respect.

Overall oral health and general wellbeing measures were used to evaluate the convergent validity of the MIS-EC. These measures are commonly employed as subjective indicators, as they are highly correlated with clinically determined oral health status. ${ }^{19}$ Statistical significance was found for all variables and the correlations ranged from weak to substantial. These coefficients were higher than those reported in the convergent validation process for the Early Childhood Oral Health Impact Scale (ECOHIS). ${ }^{1}$

Cronbach's alpha coefficient was 0.79 and 0.53 for the Child and Family Impact sections, respectively. The lower degree of internal consistency for the Family Impact section may be explained by the fact that this section only contained two items. Statistically, alpha coefficients tend to be higher for assessment tools that have a larger number of items. ${ }^{15}$ The ICC demonstrated a good degree of concordance in the test-retest results for the scores of the total MIS-EC and different sections. The evidence that supports the discriminant validity of the MIS-EC stems from the finding that children with malocclusion had higher scores than those without malocclusion, indicating greater negative impact on the OHRQoL.
Failure to perceive malocclusion in the primary dentition is often due to the fact that parents/caregivers are unaware of the aesthetic, psychological and financial consequences. ${ }^{32}$ Furthermore, there is a longstanding belief that dental health is separate from general health and should only be addressed when there is an evident problem. As children with malocclusion do not experience pain, parents/caregivers do not perceive a problem or seek treatment, but such problems could be avoided and parents/caregivers should be made aware of the importance of the prevention and treatment of malocclusion. As the perception of an adverse health condition and its impact on quality of life are associated with seeking dental treatment, ${ }^{31}$ future studies involving outpatient samples from dental clinics may find higher prevalence rates and MIS-EC scores than those reported in the present investigation. Besides that, the use of a proxy may introduce some information bias, although studies have demonstrated that proxies are an effective approach to obtain responses when studying very young children. ${ }^{33}$

Ramos-Jorge et al. ${ }^{11}$ evaluated the association between different types of malocclusion and the OHRQoL of preschool children using the ECOHIS. The authors found a significant association between anterior open bite and a negative impact on the OHRQoL, but not between increased overjet. One must bear in mind that while the ECOHIS has been validated to assess the impact of general oral health problems, it was not specifically developed to measure the impact of different types of malocclusion on OHRQoL. Thus, it is possible that this scale is not capable of detecting the influence of specific malocclusion traits on the OHRQoL of preschool children and their parents/caregivers.

Clinical and socio-demographic factors were considered potential confounding variables and were included in the adjusted analysis. Previous studies have been demonstrated that dental caries experience ${ }^{5,34,35}$ and $\mathrm{TDI}^{35}$ may exert a negative impact on the OHRQoL of preschool children. Moreover, Locker ${ }^{36}$ suggests that the relationship between oral health and quality of life outcomes is mediated by personal and environmental variables, which 
underscores the importance of including these variables in the data analysis.

Another issue is that the MIS-EC was designed to evaluate the OHRQoL of preschool children since birth (entire life rather than a short period of life). While this is generally advantageous, there are two limitations when assessing one's entire life: the period of assessment is different from child to child due to differences in age and some parents can become confused about whether they should include impacts in different periods of life. ${ }^{37}$ To minimise this limitation, the interviewers were trained to explain that the child's entire life should be taken into consideration when the parents/caregivers answered the questions and all adverse oral conditions were to be reported during the interview.

In relation to the sample size $(\mathrm{n}=381)$, sampling in assessment tool validation tests can be established based on the needs of the validation process and does not necessarily require a probabilistic sample. Some studies have suggested a number of 10 individuals that should be surveyed for each questionnaire item. ${ }^{38}$ However, studies with representative samples and well-established sampling parameters should be conducted to obtain more reliable results. The majority (87\%) of the respondents were mothers. Thus, further studies should test the MIS-EC agreement on a subsample of mothers and fathers.

Although the present investigation offers evidence about the convergent validity, discriminant validity, internal consistency and test-retest reliability of the MIS-EC, the findings should be interpreted as preliminary, as the findings are restricted to the specific population studied. Furthermore, selection and information biases may have occurred. Further studies should evaluate the responsiveness of the MIS-EC in different samples and validated adaptations done in other languages.

\section{Conclusion}

The MIS-EC is reliable and sensitive for the evaluation of the impact of malocclusion on the OHRQoL of preschool children.

\section{Acknowledgments}

This study was supported in part by Coordenação de Aperfeiçoamento de Pessoal de Nível Superior (CAPES), Conselho Nacional de Desenvolvimento Científico e Tecnológico (CNPq) and Fundação de Amparo à Pesquisa do Estado de Minas Gerais (FAPEMIG).

\section{References}

1. Pahel BT, Rozier RG, Slade GD. Parental perceptions of children's oral health: the Early Childhood Oral Health Impact Scale (ECOHIS). Health Qual Life Outcomes. 2007 Jan;5(1):6. https://doi.org/10.1186/1477-7525-5-6

2. Tesch FC, Oliveira BH, Leão A. [Semantic equivalence of the Brazilian version of the Early Childhood Oral Health Impact Scale]. Cad Saude Publica. 2008 Aug;24(8):1897-909. Portuguese. https://doi.org/10.1590/S0102-311X2008000800018

3. Huntington NL, Spetter D, Jones JA, Rich SE, Garcia RI, Spiro A 3rd. Development and validation of a measure of pediatric oral health-related quality of life: the POQL. J Public Health Dent. 2011;71(3):185-93. https://doi.org/10.1111/j.1752-7325.2011.00247.x

4. Scarpelli AC, Oliveira BH, Tesch FC, Leão AT, Pordeus IA, Paiva SM. Psychometric properties of the Brazilian version of the Early Childhood Oral Health Impact Scale (B-ECOHIS). BMC Oral Health. 2011 Jun;11(1):19. https://doi.org/10.1186/1472-6831-11-19

5. Martins-Júnior PA, Ramos-Jorge J, Paiva SM, Marques LS, Ramos-Jorge ML. Validations of the Brazilian version of the Early Childhood Oral Health Impact Scale (ECOHIS). Cad Saude Publica. 2012 Feb;28(2):367-74. https://doi.org/10.1590/S0102-311X2012000200015

6. Tsakos G, Blair YI, Yusuf H, Wright W, Watt RG, Macpherson LM. Developing a new self-reported scale of oral health outcomes for 5-year-old children (SOHO-5). Health Qual Life Outcomes. 2012 Jun;10(1):62. https://doi.org/10.1186/1477-7525-10-62

7. Abanto J, Tsakos G, Paiva SM, Goursand D, Raggio DP, Bönecker M. Cross-cultural adaptation and psychometric properties of the Brazilian version of the scale of oral health outcomes for 5-year-old children (SOHO-5). Health Qual Life Outcomes. 2013 Feb;11(1):16. https://doi.org/10.1186/1477-7525-11-16 
8. Aldrigui JM, Abanto J, Carvalho TS, Mendes FM, Wanderley MT, Bönecker M, et al. Impact of traumatic dental injuries and malocclusions on quality of life of young children. Health Qual Life Outcomes. 2011 Sep;9(1):78. https://doi.org/10.1186/1477-7525-9-78

9. Kramer PF, Feldens CA, Ferreira SH, Bervian J, Rodrigues PH, Peres MA. Exploring the impact of oral diseases and disorders on quality of life of preschool children. Community Dent Oral Epidemiol. 2013 Aug;41(4):327-35. https://doi.org/10.1111/cdoe.12035

10. Sousa RV, Clementino MA, Gomes MC, Martins CC, Granville-Garcia AF, Paiva SM. Malocclusion and quality of life in Brazilian preschoolers. Eur J Oral Sci. 2014 Jun;122(3):223-9. https://doi.org/10.1111/eos.12130

11. Ramos-Jorge J, Motta T, Marques LS, Paiva SM, Ramos-Jorge ML. Association between anterior open bite and impact on quality of life of preschool children. Braz Oral Res. 2015;29(1):46. https://doi.org/10.1590/1807-3107BOR-2015.vol29.0046

12. Wiebe S, Guyatt G, Weaver B, Matijevic S, Sidwell C. Comparative responsiveness of generic and specific quality-of-life instruments. J Clin Epidemiol. 2003 Jan;56(1):52-60. https://doi.org/10.1016/S0895-4356(02)00537-1

13. Gilchrist F, Rodd HD, Deery C, Marshman Z. Development and evaluation of CARIES-QC: a caries-specific measure of quality of life for children. BMC Oral Health. 2018 Dec;18(1):202. https://doi.org/10.1186/s12903-018-0662-8

14. Guyatt GH, Feeny DH, Patrick DL. Measuring health-related quality of life. Ann Intern Med. 1993 Apr;118(8):622-9. https://doi.org/10.7326/0003-4819-118-8-199304150-00009

15. Juniper EF, Guyatt GH, Jaeschke R. How to develop and validate a new health-related quality of life instrument. In: Spilker B, editor. Quality of life and pharmacoeconomics in clinical trials. Philadelphia: Lippincott-Raven; 1996. p. 49-56.

16. DeVellis R. Scale development: theory and applications. 2nd ed. New York: Sage; 2003.

17. Locker D, Jokovic A, Stephens M, Kenny D, Tompson B, Guyatt G. Family impact of child oral and oro-facial conditions. Community Dent Oral Epidemiol. 2002 Dec;30(6):438-48. https://doi.org/10.1034/j.1600-0528.2002.00015.x

18. Jokovic A, Locker D, Stephens M, Kenny D, Tompson B, Guyatt G. Validity and reliability of a questionnaire for measuring child oral-health-related quality of life. J Dent Res. 2002 Jul;81(7):459-63. https://doi.org/10.1177/154405910208100705

19. Jokovic A, Locker D, Stephens M, Kenny D, Tompson B, Guyatt G. Measuring parental perceptions of child oral health-related quality of life. J Public Health Dent. 2003;63(2):67-72. https://doi.org/10.1111/j.1752-7325.2003.tb03477.x

20. Jokovic A, Locker D, Tompson B, Guyatt G. Questionnaire for measuring oral health-related quality of life in eight- to ten-year-old children. Pediatr Dent. 2004 Nov-Dec;26(6):512-8.

21. Oral Health Organization. Oral health surveys: basic methods. 4th ed. Geneva: World Health Organization; 1997.

22. Andreasen JO, Lovschall H. Response of oral tissues to trauma. In: Andreasen JO, Andreasen FM, Andersson L, editors. Textbook and color atlas of traumatic injuries to the teeth. 4th ed. Oxford: Wiley-Blackwell; 2007. p. 66-124.

23. Foster TD, Hamilton MC. Occlusion in the primary dentition. Study of children at 2 and one-half to 3 years of age. Br Dent J. 1969 Jan;126(2):76-9.

24. Fayers PM. Quality of Life Assessment, Analysis and Interpretation. Chichester, UK: John Wiley and Sons, Inc; 2000. https://doi.org/10.1002/0470846283

25. Terwee CB, Bot SD, Boer MR, Windt DA, Knol DL, Dekker J, et al. Quality criteria were proposed for measurement properties of health status questionnaires. J Clin Epidemiol. 2007 Jan;60(1):34-42. https://doi.org/10.1016/j.jclinepi.2006.03.012

26. Bartko JJ. The intraclass correlation coefficient as a measure of reliability. Psychol Rep. 1966 Aug;19(1):3-11. https://doi.org/10.2466/pr0.1966.19.1.3

27. Wilson KA, Dowling AJ, Abdolell M, Tannock IF. Perception of quality of life by patients, partners and treating physicians. Qual Life Res. 2000;9(9):1041-52. https://doi.org/10.1023/A:1016647407161

28. Dhar V, Jain A, Van Dyke TE, Kohli A. Prevalence of gingival diseases, malocclusion and fluorosis in school-going children of rural areas in Udaipur district. J Indian Soc Pedod Prev Dent. 2007 Apr-Jun;25(2):103-5. https://doi.org/10.4103/0970-4388.33458

29. Carvalho AC, Paiva SM, Viegas CM, Scarpelli AC, Ferreira FM, Pordeus IA. Impact of malocclusion on oral health-related quality of life among Brazilian preschool children: a population-based study. Braz Dent J. 2013 Nov-Dec;24(6):655-61. https://doi.org/10.1590/0103-6440201302360

30. Grabowski R, Stahl F, Gaebel M, Kundt G. [Relationship between occlusal findings and orofacial myofunctional status in primary and mixed dentition. Part I: prevalence of malocclusions]. J Orofac Orthop. 2007 Jan;68(1):26-37. German. https://doi.org/10.1007/s00056-007-1606-0

31. Slade GD. Derivation and validation of a short-form oral health impact profile. Community Dent Oral Epidemiol. 1997 Aug;25(4):284-90. https://doi.org/10.1111/j.1600-0528.1997.tb00941.x

32. Stahl F, Grabowski R. Malocclusion and caries prevalence: is there a connection in the primary and mixed dentitions? Clin Oral Investig. 2004 Jun;8(2):86-90. https://doi.org/10.1007/s00784-003-0244-1

33. Rebok G, Riley A, Forrest C, Starfield B, Green B, Robertson J, et al. Elementary school-aged children's reports of their health: a cognitive interviewing study. Qual Life Res. 2001;10(1):59-70. https://doi.org/10.1023/A:1016693417166 
34. Abanto J, Carvalho TS, Mendes FM, Wanderley MT, Bönecker M, Raggio DP. Impact of oral diseases and disorders on oral health-related quality of life of preschool children. Community Dent Oral Epidemiol. 2011 Apr;39(2):105-14. https://doi.org/10.1111/j.1600-0528.2010.00580.x

35. Gomes MC, Pinto-Sarmento TC, Costa EM, Martins CC, Granville-Garcia AF, Paiva SM. Impact of oral health conditions on the quality of life of preschool children and their families: a cross-sectional study. Health Qual Life Outcomes. 2014 Apr;12(1):55. https://doi.org/10.1186/1477-7525-12-55

36. Locker D. Disparities in oral health-related quality of life in a population of Canadian children. Community Dent Oral Epidemiol. 2007 Oct;35(5):348-56. https://doi.org/10.1111/j.1600-0528.2006.00323.x

37. Jabarifar SE, Golkari A, ljadi MH, Jafarzadeh M, Khadem P. Validation of a Farsi version of the early childhood oral health impact scale (F-ECOHIS). BMC Oral Health. 2010 Apr;10(1):4. https://doi.org/10.1186/1472-6831-10-4

38. Everitt BS. Multivariate analysis: the need for data, and other problems. Br J Psychiatry. 1975 Mar;126(3):237-40. https://doi.org/10.1192/bjp.126.3.237 